\title{
MORTGAGE IN RUSSIAN FEDERATION IN SEPTEMBER 2013
}

\author{
G.Zadonsky
}

According to the data of the Central Bank of the Russian Federation, in January-August 2013 Rb 784,924bn worth of mortgage housing loans were extended which figure exceeds 1.28 times over the volume of lending in the respective period of 2012. As of September 1, 2013, the outstanding debt of Rb 2.4 trillion exceeded by 34.76\% the debt as of September 1, 2012. A positive trend of both reduction of the share of the overdue debt on MHL in rubles in the outstanding debt $(1.77 \%$ as of September 1, 2013) and growth in the volume and share of the debt on MHL without overdue payments $(96.45 \%$ as of September 1,2013$)$ in the total debt prevails. In August 2013, the monthly average rate on $\mathrm{MHL}$ in rubles fell by 0.1 p.p. and amounted to 12.4\% against 12.9\% as of April 1, 2013.

According to the data of the Central Bank of the Russian Federation, as of September 1, 2013 Rb 813,399bn worth of 518,399 housing loans (HL) were extended from the beginning of the year, including $\mathrm{Rb} 784,924 \mathrm{bn}$ worth of 485,430 mortgage housing loans which figure exceeds by $28.02 \%$ in value terms the volume of loans extended as of September 1, 2012. In August 2013, the outstanding debt on $\mathrm{HL}$ rose by $2.35 \%$ to $\mathrm{Rb} 2.51$ trillion, while that on $\mathrm{MHL}$, by $2.37 \%$ to $\mathrm{Rb} 2.4$ trillion. The latter exceeds by $34.76 \%$ the debt on MHL as of September 1, 2012. As of September 1, 2013, the overdue debt on $\mathrm{HL}$ amounted to $\mathrm{Rb} 47,932 \mathrm{bn}$, while that on $\mathrm{MHK}$, to Rb 42,448bn (Fig.1).

According to the data of the Central Bank of the Russian Federation, as of September 1, 2013 the debt on $\mathrm{MHL}$ with a period of delay in payments for over 180 days (defaulted loans) (Fig. 2) amounted to Rb 29.24bn or $1.22 \%$ of the total debt amount which figure is 1.59 p.p. lower and 0.07 p.p. higher than that as of September 1 , 2012 and August 1, 2013, respectively. In August 2013, the debt on MHL without overdue payments increased in value terms to $\mathrm{Rb} 2,312$ trillion, while that as a percentage of the total debt, by 0.37 p.p. and amounted to $96.45 \%$ (Fig. 2). In August 2013, the overdue debt on $\mathrm{MHL}$ rose (Fig. 1) by $0.33 \%$ in value terms, while that as a percentage of the outstanding debt fell by 0.04 p.p. and amounted to $1.77 \%$.

As regards the number of $\mathrm{MHL}$ extended from the beginning of the year with a cumulative result per 1,000 persons of the population, both as of September 1, 2013 and as of September 1, 2012 the leaders were the Yamalo-Nenets Autonomous Region, Khanty-Mansiysk Autonomous Region and the Tyumen Region (Table 1). The overdue debt of the above regions is also much lower than the average nationwide value. Among federal districts, as regards the number of loans per 1,000 persons the leader is still the Urals Federal District - the aggregate $15^{\text {th }}$ place against the $9^{\text {th }}$ place in 2012; the district in question retains the

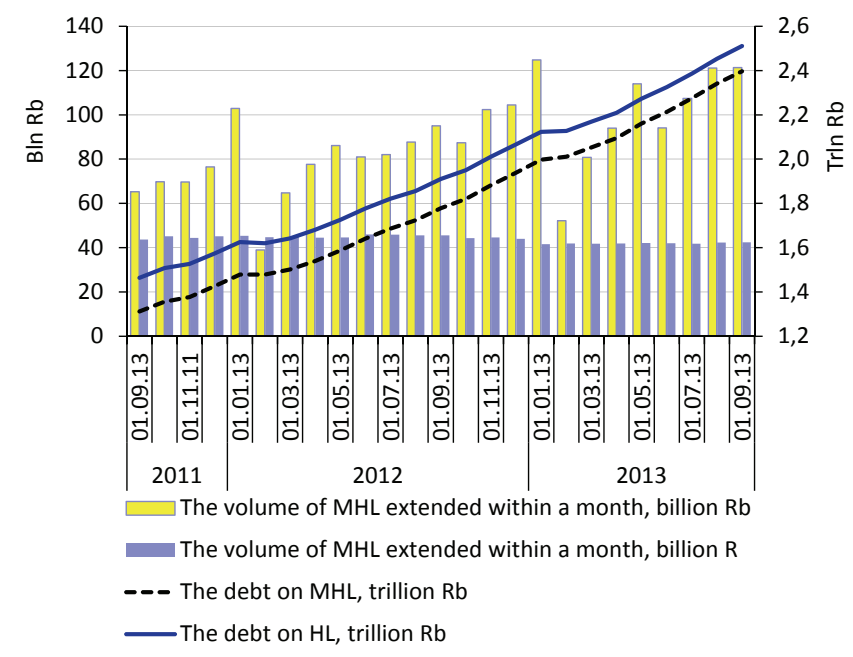

Source: the basis of the data of the Central Bank of the Russian Federation.

Fig.1. The dynamics of mortgage housing lending

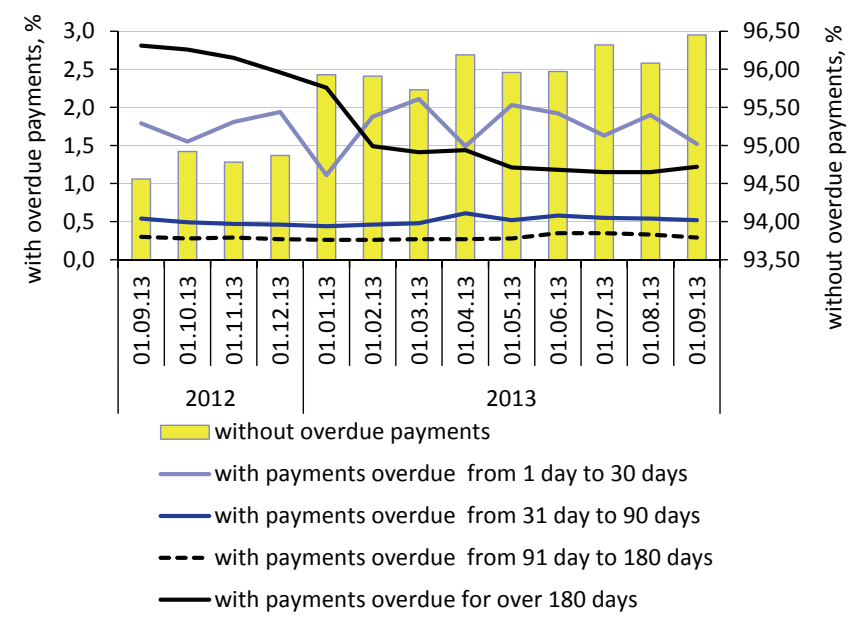

Source: the data of the Central bank of the Russian Federation.

Fig. 2. Grouping of the debt on $\mathrm{MHL}$

by the period of delay in payments in 2013

as a percentage of the total amount of the deb 
Table 1

\section{DISTRIBUTION OF REGIONS BY THE NUMBER OF MHL PER 1,000 PERSONS EXTENDED FROM THE BEGINNING OF THE YEAR WITH A CUMULATIVE RESULT}

\begin{tabular}{|c|c|c|c|c|c|c|c|c|}
\hline \multirow{3}{*}{ Region } & \multirow[b]{2}{*}{ 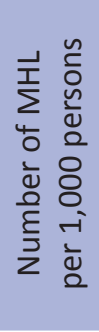 } & \multirow[b]{2}{*}{ 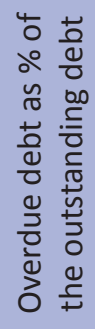 } & \multicolumn{2}{|c|}{ Place of the region } & \multicolumn{2}{|c|}{ Place of the region } & \multicolumn{2}{|c|}{ Place of the region } \\
\hline & & & 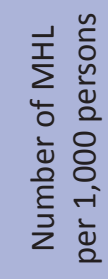 & 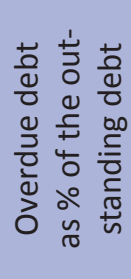 & 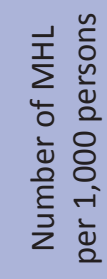 & 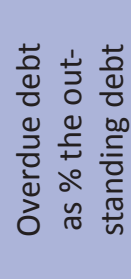 & 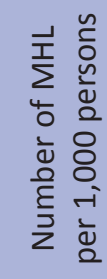 & 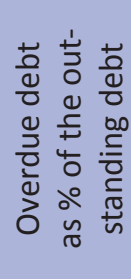 \\
\hline & \multicolumn{2}{|c|}{01.09 .2013} & \multicolumn{2}{|c|}{ 01.09.2013 } & \multicolumn{2}{|c|}{ 01.09.2012 } & \multicolumn{2}{|c|}{ 01.09.2011 } \\
\hline $\begin{array}{l}\text { Yamalo-Nenets Au- } \\
\text { tonomous Region }\end{array}$ & 6,732 & 0.15 & 1 & 6 & 2 & 8 & 2 & 9 \\
\hline $\begin{array}{l}\text { Khanty-Mansiysk Au- } \\
\text { tonomous Region }\end{array}$ & 6,156 & 0.22 & 2 & 9 & 1 & 11 & 1 & 8 \\
\hline Tyumen Region & 6,116 & 0.36 & 3 & 16 & 3 & 17 & 3 & 18 \\
\hline Republic of Udmurtia & 5,699 & 0.97 & 4 & 55 & 6 & 59 & 19 & 64 \\
\hline Republic of Komi & 5,334 & 0.26 & 5 & 11 & 11 & 12 & 11 & 14 \\
\hline Novosibirsk Region & 5,251 & 1.35 & 6 & 70 & 13 & 67 & 20 & 65 \\
\hline Republic of Tatarstan & 5,168 & 0.47 & 7 & 24 & 5 & 32 & 4 & 33 \\
\hline Ulyanovsk Region. & 5,146 & 0.52 & 8 & 30 & 16 & 19 & 13 & 24 \\
\hline Magadan Region & 5,120 & 0.03 & 9 & 2 & 17 & 5 & 24 & 6 \\
\hline Perm Territory & 5,085 & 2.31 & 10 & 83 & 15 & 80 & 16 & 78 \\
\hline Volgograd Region & 4,953 & 0.97 & 11 & 54 & 10 & 52 & 17 & 57 \\
\hline Chelyabinsk Region & 4,948 & 1.93 & 12 & 80 & 8 & 81 & 9 & 76 \\
\hline Nenets Autonomous Region & 4,931 & 0.12 & 13 & 4 & 4 & 3 & 5 & 3 \\
\hline Republic of Chuvashia & 4,833 & 0.64 & 14 & 35 & 18 & 46 & 15 & 45 \\
\hline Urals Federal District & 4,731 & 0.88 & 15 & 51 & 9 & 55 & 7 & 44 \\
\hline Privolzhisky Federal District & 4,232 & 1.12 & 21 & 61 & 23 & 61 & 22 & 62 \\
\hline Siberian Federal District & 4,050 & 1.19 & 25 & 64 & 26 & 65 & 25 & 68 \\
\hline $\begin{array}{l}\text { North-Western } \\
\text { Federal District }\end{array}$ & 3,536 & 1.29 & 37 & 69 & 43 & 66 & 45 & 60 \\
\hline The Russian Federation & 3,386 & 1.77 & 41 & 78 & 44 & 73 & 39 & 74 \\
\hline St. Petersburg & 3,255 & 1.77 & 46 & 77 & 51 & 75 & 50 & 67 \\
\hline Moscow Region & 3,232 & 4.06 & 47 & 90 & 59 & 89 & 59 & 88 \\
\hline Far Eastern Federal District & 3,126 & 0.50 & 56 & 28 & 38 & 29 & 33 & 34 \\
\hline Central Federal District & 2,846 & 3.30 & 64 & 88 & 68 & 87 & 65 & 85 \\
\hline Southern Federal District & 2,469 & 1.57 & 79 & 75 & 76 & 68 & 73 & 72 \\
\hline Moscow & 2,086 & 4.68 & 82 & 91 & 83 & 90 & 78 & 90 \\
\hline $\begin{array}{l}\text { North-Caucasian Fed- } \\
\text { eral District }\end{array}$ & 1,172 & 1.54 & 89 & 74 & 87 & 82 & 87 & 81 \\
\hline
\end{tabular}

Source: the basis of the data of the Central Bank of the Russian Federation.

$2^{\text {nd }}$ place as regards the level of the overdue debt (the aggregate 51 place) after the Far Eastern Federal District. The Central Federal District has the $64^{\text {th }}$ place and the $88^{\text {th }}$ place as regards the number of loans extended and the overdue debt, respectively, while Moscow, the $82^{\text {nd }}$ place and the $91^{\text {st }}$ place, respectively.

According to the data of the Central Bank of the Russian Federation, as of September 1, 2013 the weighted average rate on $\mathrm{MHL}$ in rubles extended from the beginning of the year fell by 0.1 p.p. against $12.7 \%$ in May, June and July 2013 (Fig. 3). The weighted average rate on $\mathrm{MHL}$ in rubles extended within a month fell by
0.1 p.p. in August 2013 and amounted to $12.4 \%$ keeping going down from the maximum value of $12.9 \%$ in March. In August 2013, the weighted average rate on $\mathrm{MHL}$ extended from the beginning of the year in foreign currency fell by 0.2 p.p., too, and amounted to $9.6 \%$.

The weighted average period of lending as regards $\mathrm{MHL}$ in rubles extended from the beginning of the year keeps reducing in 2013 and as of September 1 amounted to 14.8 years. As regards loans in foreign currency, in August 2013 the weighted average period of lending gained six months and amounted to 13.5 years (Fig. 3 ). 
In 2013, the average value of MHL in rubles extended from the beginning of the year increased to $\mathrm{Rb}$ $1.6 \mathrm{~m}$ as of September 1 (Fig. 4) having gained $10.22 \%$ as compared to September 1, 2012. Within the same period of time, the respective value in foreign currency and starting from March 2013 rose by $16.13 \%$ and amounted to $\mathrm{Rb} 7,973 \mathrm{~m}$ as of September 1, 2013.

As of September 1, 2013 the share of loans in foreign currency in the volume of MHL extended from the beginning of the year amounted to $1.33 \%$ (Fig. 5). The low volume of lending in foreign currency results in a sustained decrease in the share of foreign currency in the debt on $\mathrm{MHL}$ which amounted to $5.02 \%$ as of September 1, 2013. Along with that, the share of the overdue debt on MHL in foreign currency in the total overdue debt even increased a little in 2013 and as of September 1 amounted to $35.51 \%$, which is 2.7 p.p. higher than the minimum value as of February 1, 2013 (Fig.5). So, the share of the overdue debt on MHL in foreign currency in the total overdue debt exceeds seven times over the share of the debt on MHL in foreign currency in the total debt.

In January-August 2013, the share of the five largest banks (the first group of credit institutions ranged by the value of assets (in descending order)) in the total number of MHL extended to individuals rose to $75.3 \%$ (Fig. 6) against $58.92 \%$ in the same period of 2012. For reference: as of September 1, 2011 that share amounted to $68.83 \%$. In January-August 2013 , as compared to the respective period of 2012 the overdue debt as a percentage of the outstanding debt of the first group decreased from $2.28 \%$ to $1.47 \%$, which figure is lower than the average value of $1.77 \%$ by all the groups (the nationwide average value). As compared to the previous year, the average value by all the groups fell by 0.79 p.p. The lower quality MHL portfolio is with the second group: the share of the overdue debt exceeds by $4.4 \%$ the average value by all the groups (Fig. 6). A factor behind such a worsening can be a decrease in the volume of newly extended loans by the group with growth in the total volume of lending in the period under review.

From January-September 2013, the OAO AHML refinanced $\mathrm{Rb} 29,827 \mathrm{bn}$ worth of 22,821 MHL (Fig. 7) which is $30.66 \%$ lower than the volume of the refinanced loans in the same period of 2012. As of October 1,2013 , the share of the standard product in the total volume of the repurchased mortgage amounted to $40.65 \%$ which is 12.62 p.p. lower than the respective value in 2012; the share of military mortgage amounted to $33.68 \%$ against $8.68 \%$ the "maternity mortgage".

In August 2013, the share of mortgage loans refinanced by $A H M L$ in the total number of mortgage

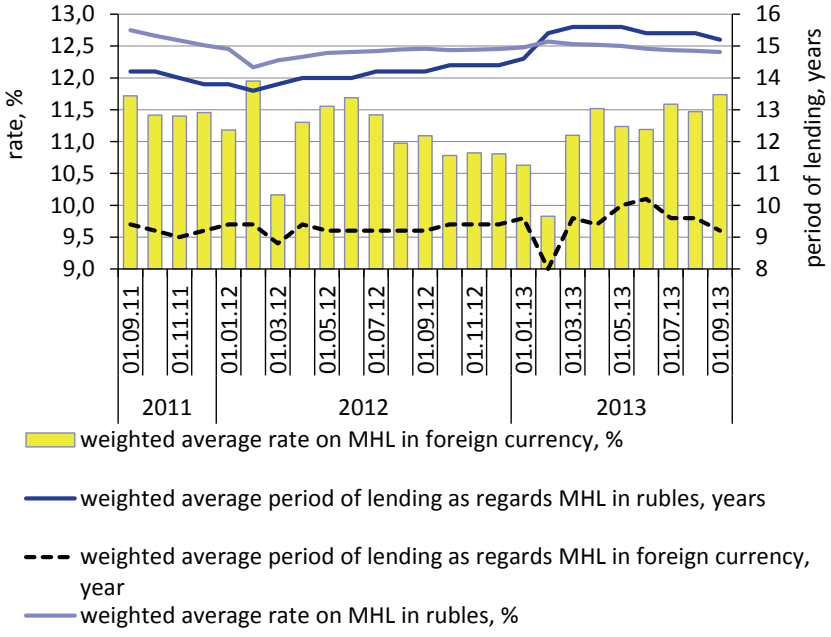

Source: the basis of the data of the Central Bank of Russia.

Fig. 3. The dynamics of weighted average rate on and the weighted average period of lending as regards $\mathrm{MHL}$ extended from the beginning of the year

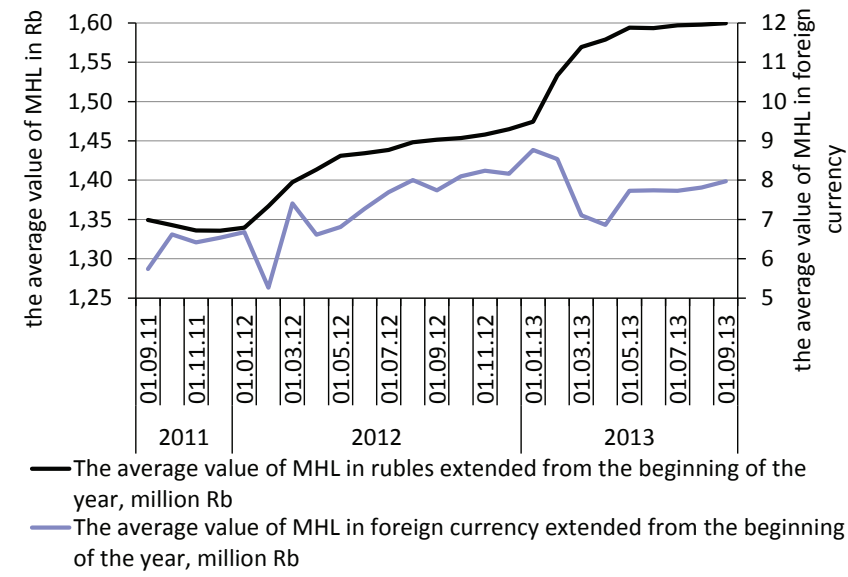

Source: the basis of the data of the Central bank of the Russian Federation.

Fig. 4. The dynamics of the average value of $\mathrm{MHL}$ extended from the beginning of the year

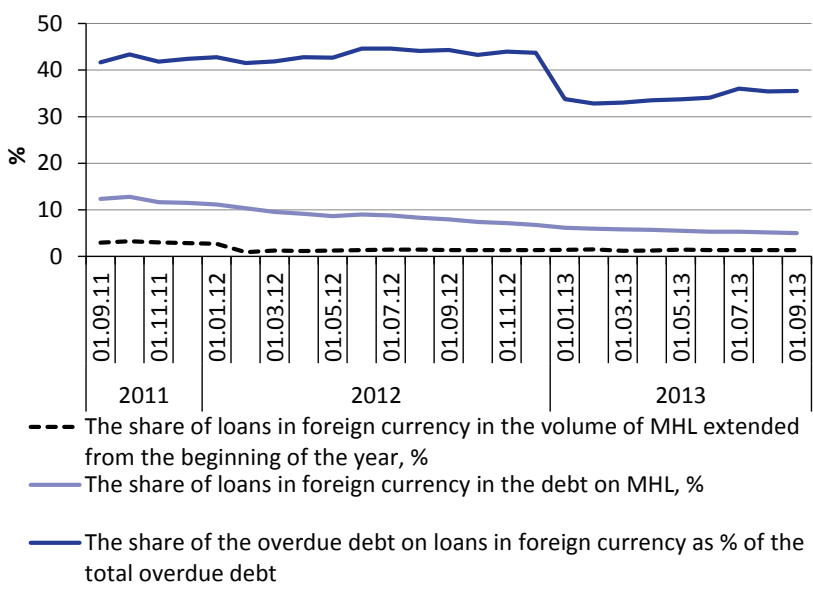

Source: the basis of the data of the Central Bank of the Russian Federation.

Fig. 5. The dynamics of the rubles/foreign currency ratio in mortgage housing lending 


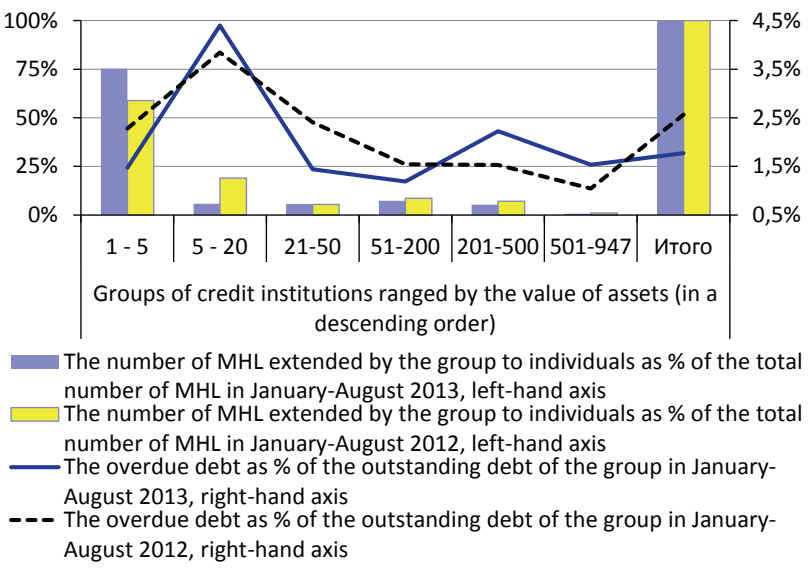

Source: the basis of the data of the Central Bank of the Russian Federation.

Fig. 6. The dynamics of volumes of MHL extend and the overdue debt by the group of credit institutions ranged by the value of assets

loans extended amounted to $2.86 \%$ which is 4.01 p.p. higher than in August 2012 (Fig. 8).

As a result of reduction of risks of securitization ensured by approval of amendments to the Federal Law on Mortgages in December 2012, the Moody's Investors Service, an international rating agency revised upwards the credit rating of the senior classes of five bond issues with AHML backing (class $A$ ) issued by ZAO Ipotechny Agent AHML 2010-1, ZAO Ipotechny Agent AHML 2011-2 and ZAO Ipotechny Agent AHML 2012-1. On the basis of the results of the meeting of the Presidium of the Council on Carrying Out of Priority National Projects and Demographic Policy under the President of the Russian Federation held on October 11, 2013, it was decided to instruct the OAO AHML to expand the practice of implementation of special mortgage programs for families with three and more children. In December, AHML plans to issue bonds secured with mortgage portfolios of several partners with the volume of about $\mathrm{Rb} 3 \mathrm{bn}$; the share of AHML in the issue amounts to about $50 \%$.

British banks have started to carry out a mortgage lending scheme proposed by the government. Under the above scheme, the initial contribution amounts to $5 \%$ of the cost of housing if the price does not ex-

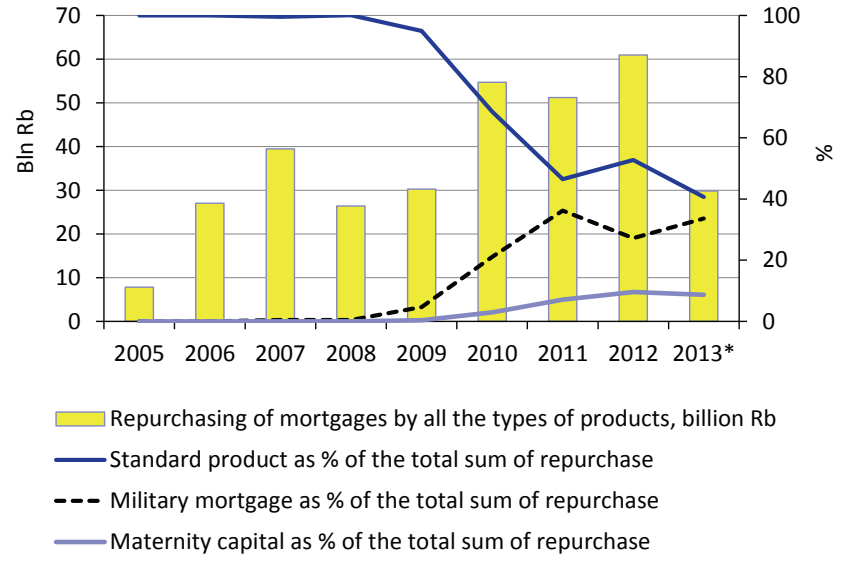

*January-September 2013.

Source: the basis of the data of the OAO AHML.

Fig.7. The dynamics of repurchasing of mortgages by the OAO AHML

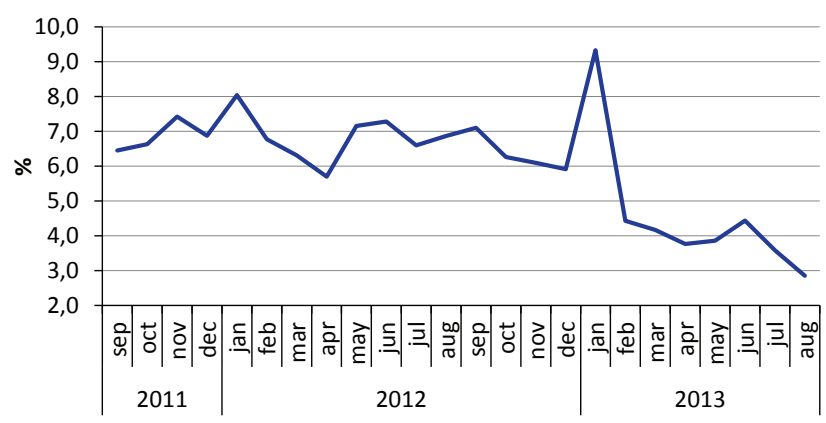

Source: the basis of the data of the OAO AHML.

Fig.8. The share of mortgage loans refinanced by AHML in the total number of mortgage loans extended within a month

ceed 600,000 pounds. Within the frameworks of the program whose volume amounts to $12 \mathrm{bn}$ pounds, it is expected to extend 180,000 mortgage loans within three years. The US Federal Agency for Financing Housing Development reported that for the purpose of securitization of mortgage loans and consolidation of some functions which are currently duplicated by state mortgage companies, that is, Fannie Mae and Freddie Mac, a new company - the Common Securitization Solutions - was established. 